\title{
Mityczna obecność Adama Mickiewicza W TWórczości TAdeusza KonwiCKIEgo
}

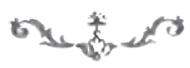

[...] jestem ostatnim, który dobrze pamięta początek XIX wieku.

Tadeusz Konwicki, Pamiętam, że było goraco ${ }^{1}$

Świat dziewiętnastowieczny trwał u nas do drugiej wojny światowej. Ja w świecie pana Adama urodziłem się i wychowałem, i on mnie żywił, uczył, bawił aż do momentu, kiedy trzeba było stamtąd czmychnąć. [...] A co z panem Adamem? My, tamtejsi, wszyscy z Niego. A On z nas.

Tadeusz Konwicki, Wiatr i pyt²

$\hat{S}$ Mierć TAdeusza Konwickiego w 2015 roku może prowokować badaczy precyzowanych kwestii jest sposób odnoszenia się pisarza i reżysera do tradycji romantycznej, zwłaszcza Mickiewiczowskiej. Zaproponowany temat wydaje się na tyle obszerny, iż z powodzeniem można by mu poświęcić osobną monografię, co wymusza nie tylko znaczące uogólnienie problematyki, ale stwarza również niebezpieczeństwo zbytnich ograniczeń i formułowania dość ogólnikowych spostrzeżeń. Dlatego też wyraźnie należy zaznaczyć, że cen-

1 T. Konwicki, Pamiętam, że było goracco, rozmawiali K. Bielas i J. Szczerba, Kraków 2001, s. 175.

2 T. Konwicki, Wiatr i pyt, teksty wybrali i do druku przygotowali P. Kaniecki, T. Lubelski, Warszawa 2008, s. 464, 470. 
tralnym zagadnieniem proponowanego ujęcia nie jest wskazanie wszystkich Mickiewiczowskich kontekstów pojawiających się w dziełach Tadeusza Konwickiego, ale próba określenia sposobu, w jaki twórczość, a czasami wręcz osoba (jeśli pojawia się trop biograficzny) Mickiewicza są obecne w utworach autora Małej apokalipsy. Rozważania skupiać się będą przede wszystkim na zidentyfikowaniu reguły strukturalnej, określającej sposób, w jaki Mickiewicz oraz związane z nim wyobrażenia i motywy, charakterystyczne też dla literatury dziewiętnastowiecznej w ogóle (np. powrót, Arkadia dzieciństwa, miłość romantyczna) egzystują w dorobku artysty dwudziestowiecznego ${ }^{3}$.

Fundamentalna dla podjętego tematu będzie teza głosząca, iż Mickiewicz, jego biografia, dzieła, związane z nim „legendy” stanowią specyficzny fenomen polskiej kultury, który, wiodąc długi żywot, przybrał w pewnym momencie kształt mitu, co stanowi właściwość konstytuującą go do dziś i określającą sposób jego egzystencji zarówno w zbiorowej świadomości Polaków, jak i w twórczości artystycznej.

Wprowadzenie tak wieloznacznego pojęcia jak mit do sfery badań nad literaturą i filmem również stwarza liczne niebezpieczeństwa, może na przykład prowadzić do niejasności wywodu czy trudności wyboru jednej z koncepcji tego fenomenu ${ }^{4}$. Wypada więc zaznaczyć, że rozważania skupią się wokół sposobu istnienia i semantyki mitu w ludzkiej świadomości, rozpatrywanych dialektycznie, w duchu hermeneutyki, z wykorzystaniem narzędzi strukturalizmu. Mit rozumiany będzie - zgodnie z propozycją Rolanda Barthes'a - jako rodzaj komunikatu, „wtórny system semiologiczny” 5 , który

3 Podobne rozważania były podejmowane w wielu pracach, między innymi przez Andrzeja Fabianowskiego, który rozpatrywał zagadnienie w odniesieniu do poststrukturalistycznej teorii intertekstualności oraz hermeneutycznej reinterpretacji pozwalającej dostrzec w dziełach autora Pana Tadeusza sensy uniwersalne, ogólnoludzkie, równie istotne jak przesłanie mesjanistyczne, narodowe. Oczywiście już znacznie wcześniej pojawiały się interpretacje Mickiewicza, skupiające się raczej na problematyce egzystencjalnej, nie historiozoficznej, czego dowodem są prace badawcze powstałe w kręgu IBL PAN, na przykład teksty Marii Janion czy Marii Żmigrodzkiej. Zob. A. Fabianowski, Tadeusza Konwickiego myślenie Mickiewiczem, w: Adam Mickiewicz i kultura światowa. Materiały Międzynarodowej Konferencji Naukowej, 1217 maja 1997 roku. Grodno - Nowogródek, w 5 księgach, księga 4, Grodno 1998; tegoż, Konwicki, Odojewski i romantycy. Projekt interpretacji intertekstualnych, Kraków 1999; tegoż, Mickiewicz - Konwicki. Przygoda intertekstualna, w: Mickiewicz a literatury słowiańskie. $Z$ dziejów recepcji od modernizmu do współczesności, pod red. E. Łoch, Lublin 2004.

4 Zob. np. E. Kuźma, Kategoria mitu w badaniach literackich, „Pamiętnik Literacki” 1986, z. 4, s. 55-73; H. Markiewicz, Literatura a mity, „Twórczość” 1987, nr 10, s. 55-70.

5 R. Barthes, Mitologie, przeł. A. Dziadek, Warszawa 20oo, s. 245-248. Identyczną za- 
jest stwarzany poprzez naddawanie znaczeń nad tekstami kultury. Według powyższego przekonania dany znak kultury wraz ze swoim signifié i signifiant zostaje poddany procesowi interpretacji i zmieniony w nowe signifiant, któremu z kolei zostaje naddane nowe signifié, dzięki czemu nad strukturą pierwotną znaku nadbudowana zostaje struktura znakowa wtórna, mająca już charakter mitu, zachowująca jednak swój sens jedynie w oparciu o znaczenie pierwotne wyjściowego znaku, co jest tożsame ze strukturą symbolu, który w myśli hermeneutycznej postrzegany bywa jako „nierozwinięty” mit ${ }^{6}$.

Podążając za tym sposobem myślenia, należy zaznaczyć, że skoro Mickiewicz i jego twórczość stają się mitem dla kultury współczesnej czy dla współczesnego pisarza, to motywy te istnieją w dziełach autora Rojstów na zasadzie paradygmatu strukturalnego, którego kolejne elementy wykorzystuje on w różnych odmianach, tak samo jak wielka literatura światowa czerpała od wieków różne warianty i dopisywała kolejne wersje mitów, odwołując się do mitemów, archetypów czy motywów rudymentarnych. Za przykłady takiego postępowania mogą posłużyć chociażby greckie tragedie będące $\mathrm{w}$ większości hermeneutykami mitów, naddającymi im uaktualniający sens i przesłanie, by nie wspominać o innych mitach wykorzystywanych przez literaturę, jak na przykład mit Hamleta, Fausta, Pigmaliona, Odyseusza czy raju utraconego. W ten sposób tworzył się łańcuch powiązań intertekstualnych, u którego początku znajdował się mit. Odwołują się do niego kolejne dzieła literackie, które w pewnym momencie same zostają obrane jako schemat czy punkt wyjściowy przez innych autorów nowszych dzieł i w ten sposób zyskują specyficzny status mitu.

Niewątpliwie utwory Mickiewicza powiązane z jego biografią stały się dla współczesnej kultury „architekstem” w rozmaitych, czasem sprzecznych czy komplementarnych, wariantach, powtarza się go, naddając mu jednocześnie kolejną warstwę znaczeń, która istnieje tylko poprzez odwołanie do znaczenia pierwotnego - w myśl opisanej przez Barthes’a zasady znaczenia mitu lub w myśl Ricœurowskiej refleksji o symbolicznej funkcji mitu, który ma moc interpretacyjną.

sadą strukturalną rządzi się opisany przez Claude’a Lévi-Straussa fenomen budowania struktur z gotowych elementów w myśleniu mitycznym, tak zwany bricolage. Zob. C. Lévi-Strauss, Myśl nieoswojona, przeł. A. Zajączkowski, Warszawa 1969, s. 37: „W toku nieprzerwanej rekonstrukcji z użyciem tych samych materiałów do roli środków powoływane są dawne cele: to, co ZNACZONE zmienia się w to, co ZNACZĄCE i odwrotnie" (wyróżn. - M.K.).

6 Zob. P. Ricœur, Symbolika zła, przeł. S. Cichowicz i M. Ochab, Warszawa 1986, s. 18-21.

7 Zob. A. Fabianowski, Konwicki, Odojewski i romantycy..., s. 17-18, 28-29. 
Powtórna realizacja mitu - zwłaszcza w przypadku Tadeusza Konwickiego - zostanie tu potraktowana poza kategorią epigonizmu ${ }^{8}$, jako reinterpretacja ożywiająca prawzór, aktualizująca go w celu naddania nowych znaczeń, sprawdzenia jego przystawalności do epoki współczesnej czy też w celu „oswojenia” współczesności przez wpisanie jej w mityczne ramy rzeczywistości konstytuowane właśnie obecnością prawzoru ${ }^{9}$.

Wskazując punkty styczne między dziełami polskiego romantyka a dorobkiem Tadeusza Konwickiego, należy zasygnalizować, na czym polega specyfika wykorzystania Mickiewiczowskiego mitu przez autora Bohini, uwydatnić charakter interpretacji mitu, uwidocznić autorską "sygnaturę” Konwickiego, która powoduje, że wykorzystanie mitu Mickiewicza nie jest czystą repetycją, ale użyciem, interpretacją, a czasem dyskusją. Jeżeli utwory Mickiewicza stanowią architekst, wzorzec, z którego czerpie Konwicki w celu przekazania własnego przesłania, to mają one zarazem strukturę swoistego „archetypu kulturowego". W myśl poglądów Lesliego A. Fiedlera literackie badania inspirowane psychologią głębi (czy popularną w dzisiejszych czasach antropologią kultury) powinny, oprócz rozpoznawania archetypów, skupiać się także na osobowym wymiarze literatury i roli biografii twórcy, w której jak w soczewce skupiają się wszystkie konteksty istotne dla pełnego odczytania intencji pisarza powołującego dzieło do życia. Kluczem okazuje się więc „umiejętność znajdowania powiązań" 10 pomiędzy archetypem (który badacz rozumie jako mit, jako „społeczną” cząstkę sfery pozaosobowościowej) a sygnaturą.

8 Por. A. Czajkowska, Mitologizacja i mistyfikacja. Twórczość Tadeusza Konwickiego wobec romantycznego powrotu do „kraju lat dziecinnych”, „Litteraria Copernicana” 2008, nr 1 (numer: Konwicki pod red. P. Kanieckiego i J. Speiny). Nieprzekonującawydaje się opinia Agnieszki Czajkowskiej, która uznaje wyzyskiwanie mitu powrotu do utraconej Arkadii wileńskiej za swoiste „kokietowanie czytelnika” (s. 63), za, degradację pamięci i bezpośredniego doświadczenia, które zastępowane jest wyobrażeniem zakorzenionym w pamięci zbiorowej” (s. 66), czy za „umiejętne manipulowanie tymi elementami tradycji literackiej, które znajdują czuły odzew w powszechnej świadomości” (s. 69), czy też „ucieczkę w sferę fikcji” (s. 69). Polemika ta wymaga jednakże osobnego studium.

9 Mit ma w swojej naturze moc interpretacyjną, strukturę składu uniwersalnych cząstek, które po odpowiednim ułożeniu przez interpretatora odpowiadają każdej sytuacji kulturowej. Opisana przez Lévi-Straussa praktyka nosi nazwę bricolage’u i może być o tyle zbieżna z procesem tworzenia literatury, o ile - co zauważył autor Smutku tropików - sama sztuka znajduje się w połowie drogi pomiędzy poznaniem naukowym a myśleniem mitycznym. Zob. C. Lévi-Strauss, dz. cyt., s. 39.

10 L.A. Fiedler, Archetyp i sygnatura. Analiza związków między biografia a poezją, przeł. K. Stamirowska, w: Współczesna teoria badań literackich za granica. Antologia, oprac. H. Markiewicz, t. 2, Kraków 1976, s. 329. 
Ten ostatni termin definiuje Fiedler jako „ogólną sumę czynników indywidualizujących zawartych w utworze, piętno Persony [Persona] czy Osobowości [Personality], przez które wyraża się archetyp, a które samo może stać się zarówno tematem [subject] utworu, jak i środkami wyrazu [means]" ${ }^{11}$.

Próbując zmierzyć się z problematyką czerpania przez Konwickiego z tradycji Mickiewiczowskiej, natrafia się na ciąg zależności intertekstualnych, który można opisać w kategoriach literackich realizacji mitycznego schematu, prawzorca literackiego ${ }^{12}$. Sytuacja taka stwarza możliwość podobną jak w badaniach narratologicznych, którym również patronował Roland Barthes postulujący odnajdywanie odpowiedników cząstek mitycznego scenariusza na trzech poziomach dzieła literackiego: funkcji, aktanta i narracji ${ }^{13}$.

\section{POZIOM FUNKCJI}

Na poziomie funkcji, czyli podstawowych, schematycznych relacji między postaciami utworów a działaniami, zauważa się liczne zależności pomiędzy dziełami Mickiewicza a Konwickiego. Najbardziej oczywiste podobieństwo wydaje się stanowić powrót bohatera „na młodości kraje”, co „buduje” analogię z Mickiewiczowskim Upiorem lub Pustelnikiem-Gustawem z Dziadów

11 Tamże, s. 331. Trzeba przyznać, że formuła ta w sposób wyjątkowo trafny zdaje się opisywać strategię pisarską Konwickiego, który sam przyznaje, że „nadużycia” w jego dziełach są jak odcisk palca. - Zob. S. Nowicki [S. Bereś], Pół wieku czyśćca. Rozmowy z Tadeuszem Konwickim, Warszawa 1986, s. 89.

12 Relację między Mickiewiczem a Konwickim można też odczytywać w kontekście hermeneutyki. Rozumienie Konwickiego przez wpływy i aluzje Mickiewiczowskie może opierać się w takiej interpretacji na zasadzie koła hermeneutycznego, w którym zarówno część, jak i całość (w tym przypadku całość twórczości Konwickiego i znajdujące się w niej motywy Mickiewiczowskie) wchodzą ze sobą w dialog wzajemnie na siebie oddziałując i prowadząc do ponownych odczytań, reinterpretacji, aktualizacji znaczeń. Jak zauważa Andrzej Fabianowski, „zapożyczając się u Romantycznego Wielkoluda, Konwicki spłaca mu dług, dokonując reinterpretacji wpisanych w jego poezję treści, przymierzając je do własnej, a więc także do naszej współczesności [...]. Zależność ta istnieje i ma charakter dwukierunkowy, nadawczy i recepcyjny" (A. Fabianowski, Mickiewicz - Konwicki..., s. 134).

13 Zob. R. Barthes, Wstęp do analizy strukturalnej opowiadań, przeł. W. Błońska, w: Narratologia, pod red. M. Głowińskiego, Gdańsk 2004, s. 13-54. Powyższa inspiracja metodologiczna stanowi wskazówkę kompozycyjną dla proponowanej interpretacji zależności między Mickiewiczem a Konwickim, jednakże trzeba podkreślić umowność i zarazem nieostrość takiego podziału, gdyż wiele aluzji czy motywów pojawia się w kontekstach stanowiących równie istotne odniesienie do każdej z trzech zaproponowanych przez Barthes’a płaszczyzn. Prowadzi to do powtarzalności niektórych obserwacji, a zarazem metodologicznej aporii, wynikającej z braku możliwości jednoznacznego klasyfikowania poszczególnych motywów. 
części IV, a także tytułowym protagonistą Pana Tadeusza. Powrót do zmitologizowanej, wręcz świętej krainy dzieciństwa stanowi jeden z centralnych motywów twórczości reżysera Salta. Należy zaznaczyć, że obraz Doliny - obszaru tęsknoty, jak i samego czasu w niej spędzonego, okresu dorastania nie jest jedynie wyidealizowany. Zawiera bowiem również pierwiastki dekonstruujące mitologiczny praczas dzieciństwa, ukazujące go jako nierozerwalnie związany zarówno z pozytywnym doświadczaniem świata, jak i z cierpieniem, samotnością, obcością ${ }^{14}$. Arkadia, do której tęsknią bohaterowie, okazuje się często istnieć tak naprawdę tylko w ich świadomości czy wyobraźni. Istotne wydają się motywacje postaci wracających na Wileńszczyznę. Tak jak „umarły dla świata”, powracają one najczęściej w celu przypomnienia sobie czy powtórnego przeżycia doznań „sielskiego anielskiego” dzieciństwa oraz odebrania sobie życia. W świecie przedstawionym powieści i filmów Konwickiego bardzo często do mitycznej Doliny przybywają tajemnicze postacie samobójców, których niejasny status ontologiczny sprawia, iż przypominają bohatera najbardziej kameralnej ze wszystkich części Dziadów. Na przykład tajemniczy nieznajomy, będący jednocześnie pochodzącym z przyszłości alter ego ${ }^{15}$ Polka Krywki w Dziurze w niebie pozostawia chłopcu rękopis, w którym obok świadectwa własnej pustej i bezcelowej egzystencji znajdują się opisy czynności dokonanych po powrocie do krainy młodości. Polek, niczym Ksiądz w IV części Dziadów, dowiaduje się, że samobójca odwiedził zrujnowany dom rodzinny, co stanowi niezwykle czytelną paralelę ${ }^{16}$.

14 Zob. D. Siwor, Między infantylizmem a dojrzałościa, czyli o dzieciństwie w powieściach Tadeusza Konwickiego, w: Kompleks Konwicki. Materiały z sesji naukowej zorganizowanej $w$ dniach 27-29 października 2009 roku przez Wydział Zarzadzania i Komunikacji Społecznej UJ oraz Wydział Polonistyki UJ, red. A. Fiut, T. Lubelski, J. Momro, A. Morstin-Popławska, Kraków 2010, s. 111-131.

15 Niemalże we wszystkich dziełach Konwickiego bohaterowie spotykają swoich sobowtórów. Dzieje się tak między innymi w Dziurze w niebie, Zwierzoczłekoupiorze, Kronice wypadków miłosnych, Czytadle czy w Lawie. Opowieści o „Dziadach” Adama Mickiewicza. Jest to motyw o proweniencji mitologicznej, wskazujący na wciąż niewyartykułowane filiacje prozy Konwickiego z sakralną mową niedyskretną charakterystyczną dla języka mitu. Jak twierdzą badacze strukturalnej szkoły tartusko-moskiewskiej, „[...] destrukcja izomorficznej świadomości sprawiła, że wszelka jednolita postać mitologiczna mogła zostać odebrana jako dwóch lub więcej bohaterów, wrogich wobec siebie. [...] Pojawienie się postaci sobowtórów - efekt rozdrobnienia mitologicznego [...] - stwarzało język fabularny", co było następstwem przeistaczania się mitologii w literaturę. Zob. J. Łotman, Z. Minc, Literatura i mitologia, przeł. B. Żyłko, „Pamiętnik Literacki” 1991, z. 1, s. 247.

16 Zob. T. Konwicki, Dziura w niebie, Warszawa 1965, s. 162: „Widać już nasz dom. Ale sczerniał, ale zdziadział. Jednym okapem wsparł się już o odkos, przymrużył oczy 
Tajemniczych samobójców jest u Konwickiego więcej. Pojawiają się w Salcie, w Jak daleko stąd, jak blisko. Pod koła pociągu rzuca się też przybysz alter ego Wicia - dorosły Witold w Kronice wypadków miłosnych, który wrócił do magicznego świata Wileńszczyzny, pozostającego poza czasem, aby jeszcze raz zaznać piękna, słodyczy i niewinności pierwszego zakochania, aby odnaleźć wartości bezpowrotnie utracone w życiu dorosłym, w świecie po największej w dziejach katastrofie kultury, w którym los skazał bohatera na powolne umieranie na raka żołądka ${ }^{17}$.

Odebrać sobie życie próbuje też Paweł na samym początku Sennika współczesnego, choć miasteczko, w którym się znalazł, stanowi nie tyle uobecnienie czystego mitu Doliny, co raczej - jak udowadniał to Jan Walc - kontaminację miasteczka z okolic Wilna lat trzydziestych i typowego polskiego miasteczka lat sześćdziesiątych ${ }^{18}$.

Kolejną reminiscencją IV części Dziadów jest sposób dokonywania obrachunku z przeszłością. Tak jak postać przybywająca w wieczór Zaduszek do domu Księdza spotyka swojego dawnego mistrza, z którym rozeszły się jej drogi i z którym dzieli ją sposób postrzegania świata ${ }^{19}$, tak też protagoniści w dziełach Konwickiego spotykają dawnych nauczycieli, przyjaciół lub zdraj-

okiem nad spróchniałą szczerbą drzwi”. Por. A. Mickiewicz, Dziady. Część IV, w: tegoż, Dzieła, t. 3: Dramaty, oprac. Z. Stefanowska, Warszawa 1995, w. 772-817.

Motyw samobójstwa jest jednym z najczęściej powtarzających się w twórczości autora Sennika współczesnego.

18 Zob. J. Walc, Tadeusza Konwickiego przedstawianie świata, Warszawa 1975, s. 5-7 (maszynopis 1407 dostępny w Bibliotece Instytutu Badań Literackich PAN w Warszawie) albo fragmenty pierwszego rozdziału tejże pracy doktorskiej - Nieepickie powieści Tadeusza Konwickiego, „Pamiętnik Literacki” 1975, z. 1, s. 87. Pierwsze pełne wydanie tej dysertacji przygotowane przez Przemysława Kanieckiego, opatrzone posłowiem Tadeusza Lubelskiego ukazało się w 2010 roku w Warszawie nakładem Agory.

19 Wizję Księdza można by nazwać harmonijną, opartą przede wszystkim na racjonalizmie, wierze w ład przedustanowiony i autorytet kościelnych dogmatów, a także wielkiej literatury. Gustaw powraca do starego mistrza jako ktoś, kto również wierzył, że taka diagnoza świata jest właściwa, ale zawiódł się boleśnie. Zrozumiał, że „model” proponowany przez Księdza nie jest w pełni adekwatny do rzeczywistości. Świat, w który wierzył, i w którym odnajdywał swoje miejsce, rozpadł się. „Starcze! a gdy ja zacznę oskarżać nawzajem, / Przeklinać twe nauki, na sam widok zgrzytać? / Ty mnie zabiłeś! - ty mnie nauczyłeś czytać!/ W pięknych księgach i pięknym przyrodzeniu czytać! / Ty dla mnie ziemię piekłem zrobiłeś / [...] i rajem! / [...] A to jest tylko ziemia!” - A. Mickiewicz, dz. cyt., w. 748-753. Ksiądz więc i Gustaw są postaciami znajdującymi się na dwóch przeciwstawnych biegunach doświadczenia, reprezentują skrajny, "jednostronny” idealizm i idealizm rozczarowany, świadomy nieprzystawalności wizji do rzeczywistości, niemożności pełnej realizacji idei w życiu. 
ców i wchodzą z nimi w konfrontację, która kończy się albo ostateczną polaryzacją stanowisk, zabójstwem, albo pojednaniem. Warto dodać, że również w Mickiewiczowskich Dziadach konfrontacja Pustelnika z Księdzem nabiera symbolicznego znaczenia walki bohatera $\mathrm{z}$ własnym cieniem, alter ego. Jak wskazuje Alina Witkowska, Gustaw w celu powtórnej integracji własnej osobowości musi zmierzyć się z dawnym nauczycielem, a zarazem swoim „sobowtórem”, uosobieniem innego „ja" protagonisty, ,ja utraconego", kierującego się prawdami racjonalnymi, egzystującego w społeczeństwie, a nie izolującego się i introwertycznego ${ }^{20}$.

Bohater Sennika współczesnego, przybywając do onirycznej rzeczywistości miasteczka nad Sołą trafia na Józefa Cara, który okazuje się nie tylko jego antagonistą, ale też zdrajcą, na którym Paweł wykonywał wyrok w Wigilię Bożego Narodzenia w czasie wojny, a co więcej, także jego dawnym nauczycielem jeszcze z czasów przedpartyzanckich, wileńskich, wreszcie zaś jego drugim „ja” (gdyż nie jest ontologicznie niezależny od Pawła) ${ }^{21}$. Podobnie bohater Jak daleko stąd, jak blisko, odbywając podróż w głąb własnej jaźni - jak większość postaci stworzonych przez reżysera Zaduszek - dręczony przez własne sumienie przeżywa w finale filmu dwie komplementarne wersje sceny z przeszłości, czyli wykonania wyroku na zdrajcy, który ma twarz jego przyjaciela Maksa, i czekania na niego w zacisznej atmosferze wigilijnego wieczoru przy kolacji w domu. W drugim wariancie sytuacji Andrzej nie zabija Maksa, odkłada broń, a między mężczyznami dochodzi do symbolicznego pojednania wyrażonego przez dzielenie się opłatkiem. Nie trzeba chyba przekonywać, że sceneria i struktura sceny rozprawy między przyjaciółmi, niczym między starym mistrzem a uczniem, przywołują sytuację z dzieła Mickiewicza.

20 Zob. A. Witkowska, Mickiewicz. Słowo i czyn, Warszawa 1983, s. 35-38. Zupełnie inaczej postrzega sytuację Zofia Stefanowska. Badaczka wskazuje na silnie polemiczny charakter IV części Dziadów. W tym kontekście Ksiądz wydaje się raczej wielkim przeciwnikiem, którego Pustelnik poddaje „próbie zdrowego rozumu”. Zob. Z. Stefanowska, Próba zdrowego rozumu: Studia o Mickiewiczu, Warszawa 1976 (studium tytułowe), s. 26-41. „[...] jest to utwór o niezwyczajnej pasji polemicznej. Do skrajności doprowadzona konfrontacja dwóch postaw życiowych" (s. 35). Na istnienie podobieństwa pomiędzy Gustawem rozprawiającym ze swoim innym „ja” a bohaterami Konwickiego spotykającymi swoje alter ego zwrócił uwagę Jan Walc, niesłusznie porzucając ten wątek badawczy, uzasadniając to faktem, że Konwicki w czasie pisania swoich powieści nie mógł znać koncepcji Witkowskiej. Zob. J. Walc, Tadeusza Konwickiego ..., s. 159.

Zob. J. Walc, dz. cyt., s. 104, 108, 150-152. 
Kwestia powrotów - realnych czy wyobrażonych ${ }^{22}$ - do krainy dzieciństwa wydaje się w przypadku twórczości Konwickiego na tyle skomplikowana, iż dotyczy zarówno bohaterów, jak i narratora wielu utworów, który jednocześnie bywa tożsamy $z$ autorem ${ }^{23}$. Przykładem takiej sytuacji może być powieść Bohiń, w której narratorem jest sam Tadeusz Konwicki „rekonstruujący" hipotetyczną, a zarazem zmitologizowaną, wersję losu nigdy niepoznanej przecież babci - Heleny Konwickiej. Takie skomplikowanie zależności między bohaterem, narratorem a autorem sprawia, że ów aspekt mógłby być poruszany równie dobrze przy omawianiu płaszczyzny narracji, a zarazem stanowi sygnaturę personalną Konwickiego, znaczenie naddane nad mitem powrotu do kraju lat dziecinnych.

Wyrażona w inwokacji i Epilogu do Pana Tadeusza tęsknota narratora pozwalała identyfikować go z przebywającym na emigracji autorem, ale Mickiewicz nie tworzył atmosfery gry autobiograficznej w takim stopniu, w jakim czynił to autor Rojstów, dla którego stała się ona swoistym „znakiem firmowym". Poza tym powrót do krainy dzieciństwa u Mickiewicza oprócz wymiaru pokutnego - kary dla samobójcy Upiora - miał wymiar kompensacyjny - jak w Panu Tadeuszu. U Konwickiego jest inaczej, bo oprócz powyższych znaczeń nabiera on także wymowy tragicznej. Bohaterowie powracający po latach spędzonych „na emigracji wyobraźni” do Doliny pragną uciec od strasznej rzeczywistości nieudanego i szarego życia, pragną odnaleźć enklawę imponderabiliów, do której nie mają wstępu ani Czas, ani $\mathrm{Hi}$ storia, a tymczasem wróciwszy do niej, wpadają w pułapkę pętli czasu ${ }^{24}$. Będąc dziećmi, pragnęli uciec z Doliny, gdyż siłą wypychającą ich stamtąd było samo życie ${ }^{25}$, naturalna podszyta witalnością chęć „wyrwania się z domu”. Będąc z kolei ludźmi dojrzałymi, pragną nade wszystko wrócić, gdyż doznają bolesnego uczucia alienacji w świecie, w którym wszystkie wartości zostały zrelatywizowane. Wracając jednak, czują się obcy po raz kolejny, gdyż mityczna Dolina istnieje tylko w ich wyobraźni i dla nich samych nie ma już tam miejsca, mogą jedynie spotkać swoich dziecięcych sobowtórów. Doznawszy tego, postanawiają odebrać sobie życie w miejscu, które tak bardzo kochają, i które przechowuje pamięć o ich dawnej egzystencji. Rękopis tajemniczego samobójcy z Dziury w niebie rozpoczyna się następującymi słowami:

22 Zob. T. Lubelski, Wędrówki realne i wyobrażone. O filmach Tadeusza Konwickiego, „Kino” 1981, nr 1, s. 2-4, 19.

23 Zob. np. B. Żynis, „To jest Konwicki, czy nie jest?”. O podmiotowości sylleptycznej, „Litteraria Copernicana” 2008, nr 1, s. 49-59.

24 Zob. P. Czapliński, Tadeusz Konwicki, Poznań 1994, s. 43-67.

25 Tamże, s. 60. 
Przedsiębiorę daleką podróż. Powracam tam, skąd kiedyś wyszedłem albo raczej - skąd mnie wygnano. Wyruszam - nie wiem po co. Może, aby ogrzać oczy krajobrazem śniącym się każdej nocy zimowej, może, by spotkać człowieka, którego nie mogę zapomnieć. A może - by umrzeć, nawet choćby nie naprawdę. ${ }^{26}$

„Proza Konwickiego opisuje nasz świat jako cywilizację obcą" ${ }^{27}$. Pisarz, nadbudowując znaczenie nad motywem powrotu do Arkadii, tworzy zupełnie nową jakość - kolejną wersję mitu tragicznego ${ }^{28}$, opisującą życie człowieka współczesnego, „stratowanego przez Historię” ${ }^{29}$, który jest obcy zarówno w świecie realnym, zdominowanym przez totalitaryzm i zło, jak i wyobrażonym, utraconym raju dzieciństwa. Literackie i filmowe utwory Konwickiego to świadectwa bolesnej i tragicznej egzystencji człowieka, który zawsze i wszędzie czuje się obcy, chciałby być gdzie indziej i tak naprawdę nigdzie, poza własnymi wspomnieniami, nie może znaleźć sobie miejsca.

Kolejnym motywem, dzięki któremu Adam Mickiewicz i jego dzieło są obecni w twórczości Tadeusza Konwickiego, jest obcowanie bohaterów z umarłymi. Jak zaznacza sam pisarz: „Ja w ogóle jestem funeralny [...]. Mówię to żartobliwie, ale to świadczy o czymś we mnie - że jestem w jakiś sposób eschatologiczny" ${ }^{30}$. Temat wspólnoty żywych i umarłych zaczerpnięty ze świata Mickiewiczowskich Dziadów animuje rzeczywistość przedstawioną w powieściach i filmach Konwickiego. Bohaterowie nie tylko bardzo często mają styczność z umarłymi, ale i sami niejednokrotnie wydają się upiorami wracającymi tam, gdzie przeżyli pierwsze wtajemniczenie w życie, czy też ludźmi umarłymi zawieszonymi między dwiema rzeczywistościami. Sytuacja taka ma przecież miejsce w powieści Wniebowstąpienie, w której wszyscy protagoniści okazują się ludźmi „W różnym stanie «umarcia»” ${ }^{11}$.

26 T. Konwicki, Dziura w niebie, s. 159.

27 Przemysław Czapliński (dz. cyt., s. 119) przywołuje konstatację ze słynnego manifestu poetyckiego reprezentantów Nowej Fali, Juliana Kornahausera i Adama Zagajewskiego (tychże, Świat nie przedstawiony, Kraków 1974, s. 38).

28 Zob. P. Ricœur, dz. cyt., s. 199-218.

29 Określenie Zygmunta Kałużyńskiego. Zob. tegoż, Psychoanaliza polskiego straconego pokolenia, „Polityka” 1961, nr 50.

30 T. Konwicki, Pamiętam, że było goraco, s. 69.

31 T. Konwicki, Patriota z noga na hamulcu, fragmenty rozmów J. Markuszewskiego z T. Konwickim, „Gazeta Wyborcza” 1996, nr 144. Por. S. Bereś, dz. cyt., s. 79-80; $Z$ Tadeuszem Konwickim o filmie "Lawa” według „Dziadów” A. Mickiewicza rozmawia Bożena Markowska, „Ethos” 1991, nr 13-14, s. 239. Na temat aspektu śmierci we Wniebowstapieniu zob. też: J. Arlt, Mój Konwicki, Kraków 2002, s. 36-46; tejże, Nocne czuwanie przy zmarlych. O „Wniebowstapieniu” Tadeusza Konwickiego, w: Oniryczne tematy $i$ konwencje $w$ literaturze polskiej $X X$ wieku, praca zbior. pod red. I. Glatzel, J. Smulskiego i A. Sobolewskiej, Toruń 1999, s. 237-244; P. Kaniecki, Noc 
Idea obcowania z umarłymi w różnych postaciach obecna jest również w wielu innych utworach autora Władzy, wystarczy wymienić Dziure w niebie, Zaduszki, Sennik współczesny, Jak daleko stąd, jak blisko, Kronike wypadków miłosnych, film Dolina Issy, Bohiń, Lawę, Czytadło.

Znów należy zapytać, w czym przejawia się oryginalność i reinterpretacja mitu tajemnej, guślarskiej, na poły pogańskiej Wileńszczyzny? Czy nie jest on u Konwickiego tylko stosowaniem zużytych, ogranych motywów z Mickiewiczowskiej rekwizytorni? Jak mówi jednak sam artysta: „To jest taki kraj, gdzie pod ziemią drzemie gorączka! Tam wszystko jest zmieszane ze sobą, a żywi i umarli wirują w szalonym tańcu" ${ }^{32}$. Idea Dziadów jest na tyle żywa w świadomości Konwickiego, że stała się „filtrem”, przez który zaadaptował on Dolinę Issy Czesława Miłosza ${ }^{33}$, oraz dominantą strukturalną innych dzieł, na przykład Zaduszek ${ }^{34}$.

Trzeba jednak nadmienić, że są to bardzo specyficzne Dziady, co właśnie stanowi o naddawaniu znaczeń, a nie tylko biernym powielaniu wzorców Mickiewiczowskich. Tak jak twórca Konrada Wallenroda, ożywiając guślarski obrzęd, wzbijał się na wyżyny romantycznej sztuki europejskiej, tak samo Konwicki, wykorzystując twórczo mit Dziadów, wpisywał własną sztukę w tendencje, które dawały o sobie znać w XX wieku. Chodzi przede wszystkim o przesunięcie akcentu z eschatologicznego wymiaru świata widm w wymiar psychologiczny. Obrzęd Dziadów nie polega już tylko na wywoływaniu duchów, ale na radzeniu sobie z własną świadomością, która jest, według Konwickiego, największym nieszczęściem człowieka, a nawet samego Boga ${ }^{35}$, na pogodzeniu się z duchami przeszłości, winami, własnymi niedoskonałościami czy kompleksami. Na tym polegają właśnie Zaduszki Wali i Michała z filmu pod tym tytułem. Podobny jest też sens tytułowe-

dożynek. Problematyka śmierci we „Wniebowstąpieniu”, „Litteraria Copernicana” 2008, nr 1, s. 105-131.

32 S. Bereś, dz. cyt., s. 85 .

33 "Moim zamiarem było zrobić z tego jakby Dziady. Oznacza to, że podpiąłem pana Czesława pod pana Adama” - S. Bereś, dz. cyt., s. 83. Zob. M. Kłobukowski, Między sielskościa a odczarowaniem. Wizje dzieciństwa w "Dolinie Issy” Czesława Miłosza i filmowej adaptacji Tadeusza Konwickiego, „Przegląd Humanistyczny” 2012, nr 5, s. $71-84$.

34 „Tytuł ma kilka znaczeń. Bohaterowie odbywają Zaduszki trochę na zasadzie Dziadów. Może dlatego w ten właśnie wieczór wracają do starych spraw? Jest wieczór w małym miasteczku, jesień, mgła, ciemnawo i szarawo... A do tego muzyka organowa" - S. Bereś, dz. cyt., s. 47.

35 Zob. S. Bereś, dz. cyt., s. 114. Por. J. Walc, Świadomość, „Litteraria Copernicana” 2008, nr 1, s. 23-31 (fragmenty drugiego rozdziału doktoratu Walca). 
go Salta, które jest zarówno tańcem, jak i skokiem bohatera w wyobrażoną przeszłość ${ }^{36}$. Nie przypadkiem w filmie pojawiają się dialogi mówiące o potrzebie obudzenia głównego bohatera, jak również określające status ontologiczny wszystkich postaci jako oniryczny, widmowy. Być może bohaterowie - co charakterystyczne dla poetyki Konwickiego ${ }^{37}$ - nie są „samodzielnymi ontycznie" postaciami, a stanowią jedynie projekcję jaźni protagonisty, który we śnie lub w wyobraźni odbywa wędrówkę do tajemniczego miasteczka kresowego. Być może więc to postacie-grzechy, jak nazywa je alter ego Kowalskiego-Malinowskiego - Artysta ${ }^{38}$. „Każdego ścigają jakieś grzechy i duchy" ${ }^{39}$ - stwierdza w jednym z wywiadów autor Czytadła. Podobne motywy można odnaleźć także w innych dziełach Konwickiego. Mająca być adaptacją Dziadów - Lawa stanowi reinterpretację arcydramatu Mickiewicza, podobnie jak i idei obrzędu. Staje się filmem, w którym umarli egzystują z żywymi tak samo, jak różne płaszczyzny czasu historycznego przenikają się w snutej przez starego Poetę „opowieści o Dziadach”. W Lawie przeszłość i teraźniejszość zostają połączone za sprawą jaźni reżysera. Tak jak adaptacja Doliny Issy ukazywała Miłosza przez pryzmat Mickiewicza, tak odczytanie Dziadów w Lawie odbyło się przez autorską świadomość Konwickiego z naniesieniem wszystkich odautorskich sygnatur na arcydzieło polskiego romantyzmu ${ }^{40}$.

Tego typu zabiegi, charakterystyczne dla twórczości Konwickiego czy wręcz rudymentarne, budujące jej niepowtarzalność, sytuują ją w planie dramaturgii wewnętrznej, charakterystycznej chociażby dla Gombrowiczowskiego Ślubu czy innych utworów, w których wraz z potrzebą dziejową dochodzi do głosu psychologia głębi, dopatrująca się dramatu w jaźni bohaterów, w ich podświadomości i pamięci. Jakże nowatorskie to przetworzenie idei Mickiewiczowskiej. To jedyne Dziady, które są możliwe dla świadka historii XX wieku. Idea obcowania żywych z umarłymi staje się w ten sposób znakiem, nad którym współczesny artysta nadbudowuje własne sensy.

36 Zob. T. Lubelski, Poetyka powieści i filmów Tadeusza Konwickiego (na podstawie analiz utworów $z$ lat 1947-1965), Wrocław 1984, s. 161.

37 Zob. J. Walc, dz. cyt., s. 104, 108, 150-152.

38 T. Konwicki, Salto. Komedia filmowa, „Dialog” 1964, nr 7, s. 59: „To zły sen. Tego miasteczka nie ma i ci ludzie nie żyją. To duchy albo raczej grzechy. Tak, nasze grzechy tułają się po nocy. Jeśli chcesz - to niech będą kompleksy".

39 S. Bereś, dz. cyt., s. 84.

40 Zob. T. Lubelski, Krewniacy z Litwy. Narodziny adaptacji z ducha wspólnoty, „Kwartalnik Filmowy” 2007, nr 59, s. 147-172; M. Kłobukowski, „Lawa”, czyli Konwickiego gra o „Dziady”, w: Scena i ekran. Przestrzeń dialogu interartystycznego, pod red. J. Skuczyńskiego i P. Skrzypczaka, Toruń 2007, s. 177-191. 
Niezwykle istotnym motywem odwołującym się do wzorca Mickiewiczowskiego jest romantyczna miłość. Jest to mit współtworzony zarówno przez IV część Dziadów, jak i legendę biografii Mickiewicza, obecny w popularnym odbiorze romantyzmu polskiego. Do jego elementów należą chociażby takie mitemy, jak niespełnienie, niezrealizowanie czy zdrada. Miłość romantyczna musi być nieszczęśliwa, niespełniona ${ }^{41}$ czy to z powodu „resztek feudalizmu" (by posłużyć się określeniem Bolesława Prusa z Lalki), czy też motywu „trójkąta”, który w popularnym odbiorze romantyzmu funkcjonuje do dzisiaj w formie: poeta - Maryla Wereszczakówna - hrabia Puttkamer. Podobnych struktur nietrudno doszukać się u Konwickiego. Już w Rojstach główny bohater w czasie rekonwalescencji wikła się w romans z narzeczoną dowódcy oddziału partyzanckiego ${ }^{42}$. W Dziurze w niebie Polek kocha się nieszczęśliwie w pochodzącej z Górnych Młynów Wisi Puciałłównie, zaś w nim samym zakochana jest Pacia, która $\mathrm{z}$ kolei nie jest obojętna koledze Polka - Kajakiemu. Schemat trójkątów miłosnych zostaje powtórzony także w Senniku współczesnym, gdzie Paweł zakochuje się w Justynie, jego samego uczuciem darzy Regina, odtrącając szaleńczo zakochanego partyzanta Jasia Krupę. W Nic albo nic główny bohater Darek ignoruje zaloty sąsiadki, ponieważ jest zafascynowany inwigilującą go milicjantką. Rację ma też Maria Janion, nazywając Wicia z Kroniki wypadków miłosnych nowym Gustawem polskiej literatury ${ }^{43}$. Romantyczna miłość utrwalona w dziełach Mickiewicza jako główny motor działań bohaterów lub powód ich nieszczęścia staje się u Konwickiego jednym z mitemów konstytuujących powrót do arkadyjskiej Doliny dzieciństwa. Łączy się także, co było istotnym rysem miłości romantycznej, znanym choćby z Romantyczności, z wymiarem epistemologicznym, szczególnie w czasie aktu erotycznego, jak na przykład w Kompleksie polskim $^{44}$. Zostaje immanentnie złączona ze śmiercią w bluźnierczej komunii zakochanych samobójców w Kronice wypadków miłosnych czy przez postać ukochanej noszącej w sobie śmierć - w Czytadle. Staje się nawet doznaniem demaskującym bezsens jedynie wyobrażonego powrotu, jak ma to miejsce

Zob. M. Piwińska, Miłość romantyczna, Kraków 1984, s. 527, 536.

42 Sytuacja stanowi jednocześnie aluzję do Wiernej rzeki Żeromskiego, konwencji romansu dworkowego, do której powrócił autor potem w Bohini. Zob. T. Lubelski, Poetyka powieści i filmów..., s. 46; P. Czapliński, dz. cyt., s. 178. Badacz nazywa Bohiń jednym $\mathrm{z}$ „najpiękniejszych romansów dworkowych, jakie powstały w polskiej literaturze powojennej” (s. 172).

43 M. Janion, Tam, gdzie rojsty. Przypadek romantycznego mediumizmu, w: tejże, Projekt krytyki fantazmatycznej: szkice o egzystencji ludzi i duchów, Warszawa 1991, s. 168.

44 Zob. T. Konwicki, Kompleks polski, Warszawa 1990, s. 95-98. 
w finale Nic albo nic - „więc coraz zajadlej poczniesz się wdzierać na ten szczyt już bliski, a jeszcze daleki, już osiągalny, a jeszcze nie zdobyty, już wyobrażony i tylko wyobrażony" ${ }^{45}$.

Jednym z istotniejszych motywów odnoszących twórczość Konwickiego do Mickiewiczowskiego archiwzorca jest też podejmowanie przez bohatera walki narodowowyzwoleńczej, a także dyskusja i buntowanie się przeciwko romantycznym księgom zbójeckim, przez których wpływ wielu młodych ludzi w partyzantce przeszło swoje wtajemniczenie w dorosłość. W nurt rozdrapywania ran i walki wpisał Konwicki swój właściwy, choć opublikowany dopiero po odwilży (1956 rok), debiut powieściowy, czyli Rojsty. W powieści pisarz ukazuje przyjmowanie wzorca romantycznej biografii bojownika o wolność jako przywdziewanie maski i naśladowanie kliszy kulturowej. Wybór pójścia do lasu i łącząca się z nim inicjacja w dorosłość nie wynikają z autentycznej potrzeby głównego bohatera, nie są owocem w pełni świadomej decyzji, ale uwikłania w grę nieautentycznych ról, są przywdziewaniem histrionicznej maski, przybieraniem quasi-teatralnej pozy, której nie należy brać do końca poważnie ${ }^{46}$. Dużo bardziej od kwestii pełnej suwerenności Polski interesuje bohatera zdobycie sympatii płci przeciwnej czy udział w zbiorowej „przygodzie” pokolenia, zyskanie podziwu i szacunku w środowisku. Konwicki demaskuje nieautentyczność bohaterów, osadzając ich w świecie pełnym „ogranych” motywów wprost $\mathrm{z}$ romantycznej rekwizytorni. Jako przykład wystarczy wymienić chociażby ryngraf z Ostrobramską, błogosławienie syna krzyżem przez matkę, wspomniany już „dworkowy" romans Stanisława z narzeczoną dowódcy podczas rekonwalescencji czy „pokazowy” żal po przypadkowym postrzeleniu kolegi ${ }^{47}$. Sztuczność roli odgrywanej przez bohatera zostaje podkreślona właśnie przez motyw nieposłusznej broni ${ }^{48}$. Znamienne dla budowania analogii z dziełami Mickiewicza wydają się też obsesyjnie powracające u Konwickiego sceny wykonywania wyroków, które - niczym najważniejsze momenty wtajemniczenia w życiu Konrada w III części Dziadów - odbywają się w sakralnym czasie najważniejszych świąt chrześcijańskich - w Senniku współczesnym jest to noc wigilijna, zaś w Nic albo nic - świt wielkanocnego poranka.

T. Konwicki, Nic albo nic, Warszawa 1973, s. 377.

Zob. T. Lubelski, dz. cyt., s. 37-39. Por. M. Janion, dz. cyt., s. 154-158.

„Błąkałem się między sosenkami, z suchymi oczyma szukając sposobu uzewnętrznienia przed plutonem swojej boleści. Zostałem umyślnie na dworze, by zagrać romantyczną komedię samotnego bólu” - T. Konwicki, Rojsty, Warszawa 1996, s. 75.

Zob. T. Lubelski, dz. cyt., s. 40-41. 
Równie istotne zależności wobec dzieła Mickiewicza można odnaleźć w twórczości Konwickiego „na poziomie” postaci. Bohater Konwickiego ma liczne cechy, które upodabniają go do protagonisty Dziadów. Przede wszystkim towarzyszy mu aura tajemniczości, która sprawia, że jego status ontologiczny wydaje się niejednoznaczny. Trudno stwierdzić, czy postacie z powieści i filmów autora Kalendarza i klepsydry to realni ludzie. Niektóre ich zachowania nasuwają skojarzenie z mitem upiora czy ducha "powrotnika” - takie wrażenie sprawiają nieznani przybysze do Doliny, co zostało już zasygnalizowane przy omawianiu mitu powrotu do kraju lat dziecinnych. Maria Janion stwierdza, że bohaterowie Konwickiego są mediumiczni ${ }^{49}$. Tacy są samobójcy z Dziury w niebie oraz z Kroniki wypadków miłosnych. Niektórzy protagoniści to po prostu duchy, o czym świadczy casus Wniebowstąpienia. Zdarzają się również takie postacie, które przez cały utwór umiejętnie grają różnymi maskami i wydają się rozdwojone do tego stopnia, że nie sposób stwierdzić, czy są ofiarami Historii, czyli tylko kabotynami, najlepiej zaś opisuje je formuła utworzona na postawie fragmentu Kompleksu polskiego ${ }^{50}$ - „tragiczny błazen”. Takim bohaterem jest, jak łatwo się domyślić, Kowalski-Malinowski z Salta. Przywdziewa on wiele masek. Od ściganego wyrokiem czy ściganego przez upiory przeszłości - poprzez romantycznego wieszcza, uzdrowiciela aż do najistotniejszych - zbawcy, Mesjasza (czym bardziej upodabnia się do Mickiewiczowskiego Konrada niż podwójnym nazwiskiem) oraz do histriona, człowieka przekarmionego literaturą, który układa własną biografię według klisz literackich z „ksiąg zbójeckich”. Nie inaczej postępuje przecież Gustaw z IV części Dziadów, który odgrywa kilka ról - tak jak bohater Salta i teatralizuje własne wystąpienie oraz samobójstwo przed Księdzem, gładko operując kliszami literackimi: gotyckimi, sentymentalnymi, romansowymi, czy balladowymi, „odgrywając całą wczesnoromantyczną "nową falę»" 51 .

W mikrokosmosie Konwickiego istnieją również postacie, które wydają się „kontynuatorami” bohaterów z dzieł wcześniejszych czy też ich innymi wariantami, chociaż na dobrą sprawę wszyscy protagoniści autora Rojstów

M. Janion, dz. cyt., s. 163.

50 T. Konwicki, Kompleks polski, dz. cyt., s. 135: „Marzył mi się traktat o tragiczności i błazeństwie. U nas często tragizm chadza pod rękę z błazenadą. A ja w tym upatruję naszą siłę. Ja kocham to dwuznaczne pokrewieństwo, tę ryzykowną symbiozę, ten geniusz narodu zamknięty w dwóch postawach”. Zob. M. Kłobukowski, „Traktat o tragiczności i błazeństwie”, czyli Tadeusza Konwickiego kompleks tragiczny, w: Kompleks Konwicki..., s. 159-183.

51 M. Piwińska, dz. cyt., s. 563. 
to „warianty” jednej archi-biografii, wcielenia jednej wzorcowej postaci. Narzuca to analogię z nie do końca oczywistą tożsamością bohatera wszystkich części Dziadów. Za przykład można podać protagonistę Sennika współczesnego, Pawła i Darka z Nic albo nic. Obu łączy, między innymi, pseudonim partyzancki - „Stary”.

Konradowi z III części Dziadów badacze przypisywali epilepsję ${ }^{52}$. Cierpi na nią również Józef Car z Sennika współczesnego. W ogóle bohaterów Konwickiego często dręczą różne choroby. Polek Krywko zapada na nierozpoznane schorzenie, Wicio w szaleńczym zakochaniu przez cały czas ma gorączkę, Charon i Darek cierpią na zanik pamięci. Głównymi problemami protagonistów Konwickiego są przeszłość, świadomość, aksjologia ${ }^{53}$ i szaleńcza romantyczna miłość związana ze śmiercią, jak w przypadku Wicia i Aliny z Kroniki wypadków miłosnych czy Michała i Wali z Zaduszek, pierwszych partnerów, których spotyka nagła śmierć. To właśnie miłość bywa dla bohatera wtajemniczeniem w zagadkę istnienia, ale równie dobrze funkcję inicjacyjną może pełnić uczestniczenie w misterium czyjejś śmierci lub poznanie prawdy i rozczarowanie perspektywą przyszłego, z góry skazanego na porażkę życia, jak ma to miejsce w przypadku Polka - „Jaka szkoda, że wszystko rozumiem" 54 - mówi w finale powieści chłopiec.

Bohaterowie Konwickiego cierpią także z powodu samotności. Używając języka Mickiewicza, wypadałoby opisać ich jako umarłych dla świata. „Na mnie nikt nigdzie nie czeka” - mówi nieznajomy samobójca do Polka Krywki w Dziurze w niebie ${ }^{55}$. To właśnie alienacja staje się powodem samobójstwa, jak również wyimaginowanego powrotu na mityczną Wileńszczyznę, co ewokuje wspomniane związki z postawą narratora Pana Tadeusza.

Poza tym bardzo często postacie Konwickiego, jeśli nawet nie są niejako z zawodu czy z powołania artystami, to dysponują świadomością twórców, układając zdarzenia $z$ własnego życia lub wyobraźniowy powrót do przeszłości według schematów zaczerpniętych z literatury. Można tak opisać bohaterów Zwierzoczłekoupiora, Salta, Lawy, Kroniki wypadków miłosnych,

Zob. J. Kleiner, Mickiewicz, t. 2: Dzieje Konrada, Lublin 1948, s. 363; R. Przybylski, Słowo i milczenie Bohatera Polaków. Studium o „Dziadach”, Warszawa 1993, s. 140. Taką interpretację choroby Konrada sugerują somatyczne objawy, zauważone przez Więźnia w scenie trzeciej dramatu: „Dla Boga, on osłabiał patrz - miota się, dąsa, / To jest wielka choroba, patrz, on usta kąsa." - A. Mickiewicz, Dziady. Czesść III, w: tegoż, Dzieła, w. 4-5.

53 Zob. J. Walc, Nieepickie powieści Tadeusza Konwickiego, s. 104-108.

54 T. Konwicki, Dziura w niebie, s. 360.

55 Tamże, s. 152. 
prawdopodobnie także Dziury w niebie i Sennika wspótczesnego. Sami okazują się narratorami opowieści, w których działają. Co więcej, ich losy są podobne do biografii autora. Pozwala to dostrzegać w nich nawet nie rezonerów, ale media samego Tadeusza Konwickiego, przez co stają się nośnikami kompromitacji iluzji świata przedstawionego ${ }^{56}$. Skoro sami opowiadają rzeczywistość, diegesis, to należy zapytać, kto z kolei jest instancją nadrzędną w stosunku do nich.

Bohaterowie Konwickiego, podobnie jak protagonista polskiego arcydramatu romantycznego, mimo rysów autobiograficznych, wypełniają swoim życiorysem paradygmat losu całych pokoleń. Nie trzeba chyba przekonywać, że dla ogromnej liczby młodych rówieśników Mickiewicza, zarówno walczący pod nazwiskiem Wallenroda i rezygnujący z miłości do kobiety Walter Alf, jak i przedkładający sprawę narodową nad szczęście osobiste Konrad z III części Dziadów ${ }^{57}$, byli wzorami do naśladowania. Pełnili jedną z najważniejszych funkcji, jaka przypada literaturze - stanowili wzorzec parenetyczny, pobudzający narodowe sumienie. Bohaterowie Konwickiego, podobnie jak ci wykreowani przez autora Grażyny, uosabiają etos dwudziestowiecznego Polaka - inteligenta, bojownika o niepodległość, który łaknąc „ładu, hierarchii i logiki” ${ }^{58}$, ulega w pewnym momencie „świetlanej wizji odbudowy państwa”, lecz później, gdy zachodzi potrzeba, gotowy jest nawet na najwyższe ofiary w imię zasad. Rzadko się zdarza, że bohater literacki - kształtowany przez ciągłe rozbudowywanie losów w odniesieniu do jednego archi-życiorysu - symbolizuje tak szerokie spektrum pokoleniowych doświadczeń. O ile protagoniści Mickiewicza stawali się symbolami dla Polaków żyjących w XIX wieku, o tyle postacie Konwickiego stanowią paradygmat zbiorowej biografii Polaka w XX wieku, niegdysiejszego filomaty, współczesnego przedstawiciela pokolenia wojennego ${ }^{59}$.

Warto również zaznaczyć, że w ostatnim filmie Konwickiego, Lawie. Opowieści o „Dziadach” Adama Mickiewicza, Wieszcz wkracza do świata przedstawionego niemal dosłownie - za sprawą roli Poety odgrywanej przez Gu-

Zob. J. Walc, dz. cyt., s. 89-91; T. Lubelski, Wędrówki realne i wyobrażone...; tegoż, Bohater Konwickiego, w: Człowiek z ekranu. Z antropologii postaci filmowej, pod red. M. Jankun-Dopartowej i M. Przylipiaka, Kraków 1996, s. 63-71; tegoż, Siedem powodów niezbędności, „Kino” 2001, nr 6, s. 10-11.

58 T. Konwicki, Nic albo nic, Warszawa 1973, s. 88.

59 Pamiętać należy, że wzorzec biograficzny Bohatera Polaków stworzony w dziełach Mickiewicza był postulatywny, inaczej przedstawia się status protagonisty w twórczości Konwickiego, który jedynie może być odczytywany jako nosiciel zbiorowego obrazu Polaka-inteligenta doświadczonego przez wiek XX. 
stawa Holoubka, poniekąd jest starym mistrzem wracającym we wspomnieniach czy we śnie „na paryskim bruku” do ukochanego miasta ${ }^{60}$, poniekąd starym, dojrzałym już Konradem ${ }^{61}$, staje się także nośnikiem innych znaczeń naddanych, będąc niejako samym Holoubkiem „mierzącym” się po latach ze swoją najsłynniejszą teatralną rolą, a także wysłannikiem samego Konwickiego $^{62}$. „Mickiewicz staje się tu bohaterem literackim tak samo, jak bohaterem literackim staje się autor książki. Zaś między oboma twórcami (i wszystkimi twórcami) zostaje zawiązana więź krwi, oznaczająca przynależność do jednego kulturowego uniwersum" "63. Z kolei w Czytadle Mickiewicz jest również jednym $z$ bohaterów, ale tym razem okazuje się on potomkiem Mickiewicza, emigrantem, który zbił w Stanach Zjednoczonych fortunę na książce o wypróżnianiu, i który wybawia bohatera z poważnych kłopotów. Zabieg taki stanowi echo licznych deklaracji pisarza, który podkreśla swój familiarny stosunek do Wieszcza Polaków jako do starszego kolegi po piórze, sąsiada z Litwy czy wręcz jako przodka z magicznej krainy wileńskiej. Warto też nadmienić, że postać ta egzystuje jako mitologem, czyli zwinięty do imienia własnego ułamek ,tekstu mitologicznego, metaforycznie konfrontujący zjawiska ze świata mitu i świata historii oraz metonimicznie zastępujący całościowe sytuacje i fabuły" ${ }^{64}$. W ten sam sposób funkcjonuje Charon we Wniebowstapieniu, a poniekąd także Helena Konwicka w Bohini.

Dopatrując się opalizacji znaczeń mitu Mickiewiczowskiego bohatera ro-

60 Por. wypowiedzi Konwickiego, iż Lawa miała być już w zamyśle filmem o Mickiewiczu, np. W szponach romantyzmu. Z Tadeuszem Konwickim rozmawia Elżbieta Sawicka, „Odra” 1988, nr 1, s. 22-31. Zob. także P. Kaniecki, „Lawa” Tadeusza Konwickiego jako „film o Mickiewiczu na podstawie "Dziadów»", w: Biografistyka filmowa. Ekranowe interpretacje losów i faktów, pod red. T. Szczepańskiego i S. Kołos, Toruń 2007.

61 Reżyser w eksplikacjach autorskich podkreślał, że tylko człowiek dojrzały, doświadczony przez życie może wadzić się z Bogiem, nie narażając się na śmieszność. T. Konwicki, $W$ szponach romantyzmu, s. 27: „Będzie to powrót Mickiewicza - jako upiora czy po prostu jako człowieka niemogącego zasnąć w Paryżu - na Litwę. To on będzie bohaterem. On będzie Widmem, Pustelnikiem, a także częścią Gustawa-Konrada. On powie Wielką Improwizację. Ponieważ nie może jej mówić - dla mnie nie może, ja sobie tego nie wyobrażam - młody Konrad. Mnie to zawsze śmieszy, kiedy w imieniu narodu bierze się za bary z Bogiem chłopiec".

62 Zob. Z. Majchrowski, Improwizacja jak, „lawa”, w: tegoż, Cela Konrada. Powracajac do Mickiewicza, Gdańsk 1998, s. 191-192; T. Lubelski, Krewniacy z Litwy....; T. Miczka, Wielka improwizacja filmowa - „Opowieść o »Dziadach « Adama Mickiewicza Lawa” Tadeusza Konwickiego, Kielce 1992, s. 6, 13; M. Kłobukowski, dz. cyt.

63 A. Fabianowski, Konwicki, Odojewski i romantycy..., s. 67.

64 Zob. J. Łotman, Z. Minc, dz. cyt., s. 260. 
mantycznego, ujętego przez Tadeusza Konwickiego w formie postaci dwoistej, przywodzącej na myśl trickstera ${ }^{65}$, łatwo wskazać sensy naddane przez autora Małej apokalipsy nad mitem Gustawa-Konrada. Jednym z najbardziej istotnych rysów wydaje się przesunięcie akcentów znaczeniowych - charakterystyczne także dla poziomu funkcji - ze sfery wyobrażeń eschatologicznych, sfery pierwiastka fantastycznego (choć i taki poziom znaczeń u Konwickiego bezsprzecznie istnieje, o czym świadczy choćby korowód widm z Wniebowstąpienia) na poziom psychologii, życia wewnętrznego. Ma to związek z Konwickiego koncepcją "urealniania cudów” "66 i realnego spojrzenia na kontakty z duchami czy w ogóle ze sferą transcendencji, a także na odczytywanie Dziadów Mickiewicza jako dzieła całkiem realistycznego.

Urealnianie cudów, to jest moja idée fixe! [...]. Przeczytałem niedawno Dziady na nowo i bez pomocy literaturoznawców oraz teatrologów doszedłem do wniosku, że jest to bardzo realistyczny utwór. Mickiewicz uważał się za realistę. Ja także uważam się za realistę. W absolutnie trzeźwy sposób zakładam, że istnieją duchy, mary i diabeł, albo może ktoś inny, kto pełni jego funkcje. Wszystkie nielogiczności i nadnaturalności mojej prozy są możliwe do logicznego wytłumaczenia. [...] bardzo przyjaźniłem się z Dygatem. Przecież ja czasem z nim i teraz rozmawiam. Z kolei dawno zmarłego Wilka Macha proszę czasami, by mi w czymś pomógł. [...]. Nie traktuję tego bynajmniej w kategoriach duchologii, lecz realności i gdybym miał więcej cierpliwości, poszukałbym na to racjonalnych uzasadnien. ${ }^{67}$

Dwoiści bohaterowie nie są u Konwickiego tylko gośćmi z zaświatów, stają się łącznikami diegesis literatury czy filmu ze światem realnym, stanowią wielką aluzję do samego autora i jego świadomości. Łączą poziom fikcji z poziomem metaliterackim czy metafilmowym. Nadbudowują nad światem

65 Nadrzędnym rysem charakterologicznym, a nawet ontologicznym bohatera wydaje się taka sama właściwość, która konstytuowała istnienie Doliny i miasteczka - czyli dwoistość. Gdyby chcieć odnaleźć odpowiadający takiej konstrukcji bohatera fenomen w dziedzinie antropologii, najlepiej przystawałby do niej tzw. trickster, czyli postać mityczna, pojawiająca się w mitologiach ludów zamieszkujących zarówno Europę, jak i Amerykę, będąca charakterem dwoistym, pośrednikiem pomiędzy dwoma światami, mającym za zadanie pojednać niebo i ziemię czy bóstwem o dwóch ambiwalentnych obliczach. Uosobieniem takiego archetypu postaci wydają się takie mityczno-baśniowe postacie, jak Kopciuszek czy Dyl Sowizdrzał. Odpowiada to również gnostyckim podaniom o zbawicielu pochodzącym z nizin społecznych. Zob. C. Lévi-Strauss, Antropologia strukturalna, wstępem poprzedził B. Suchodolski, przeł. K. Pomian, Warszawa 1970, s. 307-315. Por. P. Radin, Trickster. Studium mitologii Indian pótnocnoamerykańskich, przeł. A. Topaczewska, koment. K. Kerényi i C.G. Jung, posł. L. Kolankiewicz, Warszawa 2010.

67 Tamże, s. 8o, 135. 
wewnętrznym utworów perspektywę kompromitującego ich iluzję artysty, którą to postawę z powodzeniem można by odczytać jako przykład ironii romantycznej.

\section{POZIOM NARRACJI}

Równie wiele reinterpretacji i nawiązań do mitu wielkiego romantyka można odnaleźć u Konwickiego na poziomie narracji. Wystarczy wskazać chociażby wielokrotnie już wspominane budowanie mitu kresów, mitu Wileńszczyzny jako Arkadii dzieciństwa, enklawy tolerancji, niezwykłego miejsca na mapie Europy, stanowiącego skansen wieku XIX do rozpoczęcia drugiej wojny światowej ${ }^{68}$. Słusznie zauważa Andrzej Fabianowski, że ziemia staje się w tym wypadku tekstem, że region budzi określone konotacje w świadomości odbiorców i twórców ${ }^{69}$. Nie byłoby Doliny Konwickiego, gdyby nie istniał mit ustanowiony przez dzieła Mickiewicza, od Ballad i romansów poczynając $^{70}$. Litwa Mickiewicza, Litwa szeptunów i zamawiaczy, Litwa samobójców i upiorów, Litwa zarówno idealizowanego, jak i dekonstruowanego czasu dzieciństwa i Litwa walk narodowowyzwoleńczych w powieściach i filmach Konwickiego zostaje ukonstytuowana na nowo, ożywa, aby współtworzyć kolejny wielki, na poły romantyczny mit. Tak jak u Mickiewicza była symbolem archetypowej Arkadii, kraju lat dziecinnych, który „Zawsze zostanie święty i czysty, jak pierwsze kochanie”, i gdzie każdy uciekinier czy emigrant mógł znaleźć schronienie, tak u Konwickiego staje się przestrzenią podwójnego wygnania, enklawą wartości, do której chce się wracać, ale która nie istnieje już nigdzie indziej poza wyobraźnią. To właśnie świadomość nieodwracalnej śmierci Doliny i fikcyjności wszelkich powrotów buduje tragizm tego miejsca u autora Nic albo nic.

W dziełach Konwickiego - zwłaszcza w sylwach współczesnych - często występują odwołania do charakterystycznej dla Mickiewicza idiomatyki, co zostało skrupulatnie ukazane w pracy Andrzeja Fabianowskiego. Odwołania do słynnej kwestii o „lawie” we Wschodach i zachodach księżyca przy okazji podjęcia problematyki narodowej czy kult młodości we fragmentach Nowego Świata i okolic wydają się oczywistej proweniencji ${ }^{71}$. Nie inaczej należy interpretować kwestie, takie jak refleksja na temat roli literatury (zwłaszcza Stefana Żeromskiego), w którą bezapelacyjnie i bezgranicznie wierzyło całe po-

68 Zob. T. Konwicki, Mickiewiczowie młodsi, w: tegoż, Wiatr i pył, s. 464.

69 A. Fabianowski, Konwicki, Odojewski..., s. 21.

70 Zob. T. Konwicki, Pamiętam, że było goraco, s. 165-181 (rozdz. Gdybym pochodzit $z$ Bydgoszczy).

71 Zob. A. Fabianowski, dz. cyt., s. 48. 
kolenie pisarza; „ksiąg zbójeckich” wpajających imperatyw śmierci za Polskę $^{72}$; uwagi o wierze pokolenia wojennego w mesjanizm, łącznie z odwołaniem do pojęcia Polski-Chrystusa narodów ${ }^{73}$, o narodach uwięzionych i ubezwłasnowolnionych ${ }^{74}$ czy o chorobie pisarza "na naród” 75 ; wzmianki o sobie samym lub o artyście jako o człowieku, który wadzi się z Bogiem ${ }^{76}$; nazwanie Popiołu i diamentu Andrzeja Wajdy dzisiejszym Panem Tadeuszem $^{77}$; poruszenie tematu samego Adama Mickiewicza i jego tęsknoty za prowincjonalnością Litwy czy walki z Panem Bogiem ${ }^{78}$; liczby $44^{79}$; współżycia Polaków i Żydów w dawnej Polsce ${ }^{80}$ oraz wspominana kwestia Gustawa Holoubka i jego teatralnej roli Bohatera Polaków w adaptacji Dziadów ${ }^{81}$. Nie można pominąć także tak istotnych sposobów tworzenia narracji przez Konwickiego, jak umiłowanie szczegółów i kolorytu lokalnego - zwłaszcza w partiach dotyczących Wilna i okolic - co przecież było rysem konstytutywnym wielu dzieł Mickiewicza ${ }^{82}$, decydowało o jego nowatorstwie i oryginalności, wywodziło się z fascynacji ludowością.

Znamienny wydaje się także żywioł gawędowy ${ }^{83}$, którym wprost kipią sylwy Konwickiego, a który jest przecież charakterystyczny dla twórczości Mickiewicza, zwłaszcza dla licznych partii Pana Tadeusza ${ }^{84}$. Pisarz sam wprost nazywa się „ostatnim szlacheckim gawędziarzem” ${ }^{85}$, po czym wyprowadza genezę „nowego” stylu własnej prozy z facecji, w których atmosferze dorastał na Wileńszczyźnie. Współczesne „gawędy” Konwickiego zawierają inspiracje i wątki Mickiewiczowskie na wielu poziomach, nie tylko poprzez odwołanie do Mickiewiczowskiej idiomatyki. Na przykład warto wymienić powracające w łże-dziennikach zwroty i refleksje dotyczące krytyków literackich, polemiczne, skrzące się złośliwościami, ironicznym dystansem, przywołujące

72 T. Konwicki, Kalendarz i klepsydra, Warszawa 2005, s. 62-63.

73 Tamże, s. 61, 66.

74 Tamże, s. 256.

75 T. Konwicki, Wschody i zachody księżyca, Warszawa 1990, s. 16.

76 T. Konwicki, Kalendarz i klepsydra, s. 77; Zorze wieczorne, Warszawa 1991, s. 25; Nowy Świat i okolice, Warszawa 1990, s. 56.

77 T. Konwicki, Wschody i zachody..., s. 59.

78 T. Konwicki, Kalendarz i klepsydra, s. 80, 134.

79 T. Konwicki, Nowy Świat..., s. 221.

80 T. Konwicki, Kalendarz i klepsydra, s. 269.

81 Tamże, s. 340-343.

82 Zob. A. Fabianowski, dz. cyt., s. 51.

83 Tamże, s. 51-52.

84 Z. Szmydtowa, Czynniki gawędowe w poezji Mickiewicza, „Pamiętnik Literacki” 1948, s. $298-334$.

85 T. Konwicki, Nowy Świat ..., s. 72. 
choćby słynny tekst poety O krytykach i recenzentach warszawskich. Dłuższy passus poświęcony temu zagadnieniu pojawił się w Kalendarzu i klepsydrze, gdzie obok autorskiej typologii krytyków można odnaleźć odwołanie do dorobku Wieszcza.

Naszła mnie nagle dzisiaj ochota, aby popieścić się z krytykami. W końcu żyję śród nich tyle lat i codziennie odczuwam ich obecność. A to któryś poczochra mi raptem pobłażliwie włosy, a to szczypnie boleśnie w policzek, a to kopnie znienacka i odejdzie sobie jak gdyby nigdy nic. Przyzwyczaiłem się do nich, polubiłem te permanentne zaczepki, pokochałem właściwie ową czujną ich obecność, którą słyszę za plecami. [...]

Szacunek musi budzić także gatunek krytyka wściekłego. Krytyk wściekły jest wściekły charakterologicznie. Jeśli znielubi ciebie od pierwszego wejrzenia, to żebyś później same Księgi pielgrzymstwa rodził, i tak go nie udobruchasz, nie rozchmurzysz, nie rozśmieszysz. ${ }^{86}$

W podobnym tonie utrzymane są uwagi dotyczące chociażby krytycznej recenzji Nic albo nic, napisanej przez Aleksandra Fiuta ${ }^{87}$.

Bardzo istotną kwestią składającą się na problem gawędowości w sylwach autora Rojstów są zapożyczenia stylistyczne nawiązujące do twórczości Mickiewicza. W wielu fragmentach Konwicki nie tylko czyni aluzje do stylu konkretnych dzieł Wieszcza, ale i zarazem nawiązuje do ich treści, choć - co trzeba podkreślić - wszystkie te nawiązania okazują się kreatywne, przekształcają oryginał, dostosowują go do sytuacji lub przemyśleń pisarza, czasami nawet manifestują dystans artysty współczesnego do samego siebie jako swoistego dziedzica tradycji Mickiewiczowskiej.

Polsko, ojczyzno moja, ty jesteś jak zdrowie dla chorych na ambicję literatów. Ile cię cenić trzeba, ten tylko się dowie, kto wydawał książki na Zachodzie. Polski narodzie, ostatni z narodów, który czyta wiersze i powieści!

Śliczna, dziwna prowincjo nadwiślańska, gdzie Ulissesa wydaje się w masowym nakładzie jak kryminał, gdzie ludzie łamią sobie żebra na mityngach poetyckich, gdzie białogłowy tracą dziewictwo z miłości do drukowanego słowa!

Świat Pierwszy, Świat Zachodni pogrąża się jak Atlantyda w oceanie wtórnego analfabetyzmu. Umie jeszcze rozpoznawać symbole notowań giełdowych, z trudem czasem przesylabizuje sprośną albo krwawą sensację, kulfonami podpisze niekiedy jeszcze jeden akt totalnej niemocy, albo bezwarunkowej kapitulacji. Świat zachodni nie spali już nigdy na stosie książek, bo nie ma co palić. [...]

Tylko my, Świat Drugi, a właściwie Międzyświat, połykamy łapczywie książki, zagłuszając w sobie głód, ale głód czego? Czemu Opatrzność tuczy nas słowami jak gęsi przed zarżnięciem? Dlaczego, żyjąc w fikcji, szukamy rzeczywistości w zmyśleniach?

86 T. Konwicki, Kalendarz i klepsydra, s. 36-37, 37-38.

87 Tamże, s. 206-207. 
Ja tu gadu-gadu, a tymczasem leciwi koledzy podrywają mi żonę. Ja wzlatuję we wzniosłość, wadzę się z Bogiem, rozplątuję zagadkę bytu, a tu starzy lubieżnicy rwą czcigodną matkę dorosłych dzieci. Oto przykład powszechnego upadku obyczajów. Oto dotkliwy symbol Wielkiego Kryzysu. Starości, podaj mi rogi!

Żarty żartami, ale jak tu znaleźć się w takiej sytuacji? ${ }^{88}$

Powyższy, obszerny, fragment zawiera odwołania do Pana Tadeusza, nie tylko do inwokacji, ale też do epilogu - poprzez skontrastowanie „upadającego", pozbawionego głębi świata Zachodu i Polski czy Słowiańszczyzny, która nie podlega idealizacji, zostaje oceniona, co znamienne dla Konwickiego, równie krytycznie. Krótki dopisek z kolei zawiera aluzję do Wielkiej Improwizacji, a zarazem ironiczną parafrazę Ody do młodości, kończy się z kolei żartobliwą uwagą świadczącą o dużej dozie dystansu do samego siebie i własnego pisarstwa.

Podobnie śladem poety jest pojawiająca się w narracji sylw perspektywa kosmiczna, przywołująca Wielką Improwizację ${ }^{89}$, czego dowodzi chociażby następujący fragment Wschodów i zachodów księżyca:

Rozczłonkowana materio biologiczna, mikroby pasące się na wulkanie śmiercionośnego tlenu, ślepe i głuche kamienie lecące w przepaść niebytu, wzywam was do buntu, do rebelii, do krnąbrnego, zawziętego, wściekłego oporu. Odrzućmy czołobitność wobec naszego Pana, przestańmy mu schlebiać i służyć wiernie, przestańmy mu oddawać cześć boską. On nie dba o nas, on poszedł gdzieś dalej i nas już nie widzi, jemu na nas nie zależy i jest mu obojętne, czy żyjemy na naszych mizernych wysokościach intelektualno-moralnych, czy umieramy w podłości i grzechu. On zażartował i pokuśtykał niefrasobliwie z powrotem do środka kosmosu, bo on jest, zdaje się, takim samym niedołęgą jak my, jego marne odbicia w staroświeckim, niemodnym lustrze genetycznym..$^{90}$

Niezwykle istotne na poziomie snucia opowieści i ich kształtowania wydają się także zbieżne idee cykliczności dzieła. Jak wskazuje Bogusław Dopart, „Mickiewicz przejawiał stałą skłonność do łańcuchowego zestawiania utworów [...]. Cykl romantyczny nie musi mieć jakiejś nadrzędnej ramy; jego ogniwa mogą się lokalnie zazębiać czy stykać nieraz zupełnie peryferyjnymi cechami" ${ }^{91}$. Biografia twórcza Mickiewicza nabiera w takim kontekście kształtu, który polega na ciągłym pisaniu „tego samego utworu, streszczającego w kolejnych wariantach egzystencję twórcy", co stanowi syn-

88 T. Konwicki, Kalendarz i klepsydra, s. 357-358.

89 Zob. np. A. Fabianowski, Mickiewicz-Konwicki..., s. 139, 147.

90 T. Konwicki, Wschody i zachody..., s. 82. Podobnych fragmentów utrzymanych w perspektywie globowej można wskazać więcej, np.: Nowy Świat, s. 163.

91 B. Dopart, Poemat profetyczny. O „Dziadach” drezdeńskich Adama Mickiewicza, Kraków 2002, s. 82, 88. 
tezę poezji romantycznej ${ }^{92}$, a zarazem niezwykle upodabnia ją do biografii twórczej Konwickiego - czyli do realizowania ciągle pewnego archiscenariusza losów jednego bohatera, zawierającego różne warianty czy może nawet - posługując się językiem filologów klasycznych badających mit - motywy rudymentarne ${ }^{93}$.

Z powyższym aspektem związana jest kwestia łączenia - co już samo $\mathrm{w}$ sobie jest przecież romantyczne - sztuki z autentyzmem ${ }^{94}$, literatury z biografią. O fascynacji takim połączeniem, jak również fascynacji samym życiem Mickiewicza, fascynacji samego narratora dzieł Konwickiego, który staje się często ich bohaterem, a bywa także utożsamiany z autorem, fascynacji, która prowadzi do przenoszenia techniki kreacji życia na literaturę a literatury na zapis autentycznych doświadczeń życiowych świadczą najlepiej następujące słowa:

My, to znaczy moje pokolenie wileńskie, powtarzaliśmy ich życiorys. Każdy z nas spotkał swoją Marylę. Każdy z nas z ogromną czupryną, pełen wielkich nadziei wobec przyszłości, każdy z nas chmurnym wzrokiem zerkał na swego Puttkamera, który mógł być kapitanem akowskim traktującym nas pobłażliwie. [...]

Ja także, niechcący, nieświadomie, tak jak wszyscy piszący, naśladowałem ukradkiem Wieszcza rodaka. Otóż kilka razy pozwoliłem sobie w swoich książkach przymknąć osobisty aparat kontrolny i puścić na niewinne kartki rękopisu strumień refleksji czy emocji nieprzemyślanych, nieostrożnych, nieregulowanych kalkulacją. Po prostu pisałem to, co samo spływało z pióra i z podświadomości.

I co z tego? Nic. Po prostu tak się zdarzyło. 95

W ten sposób Konwicki, nie po raz pierwszy zresztą, zdradza tajniki własnego warsztatu pisarskiego i podkreśla romantyczną proweniencję własnej twórczości. Romantyczne są bowiem tematy, postacie, problematyka dzieł, odwołania do mitu Mickiewicza, jak i samo przetwarzanie owego wielkiego mitu polskiej kultury przez pryzmat własnej osobowości twórczej, będące niczym innym jak z gruntu romantycznym sposobem ekspresji autorskiego „ja”, waloryzacją jednostkowej egzystencji, partykularnej biografii, własnej podmiotowości pisarskiej.

Ostateczny powrót do świata Archetypów, osiągalny nawet w naszej zatomizowanej kulturze, to rozwinięcie drogi instynktownie poszukiwanej przez romantyków - poprzez osobowość poety, jego indywidualne słabości i dziwactwa, aż do jądra jego nieświadomości, gdzie identyfikuje się on z nami w obliczu naszych dawnych bogów

92 Tamże, s. 83.

93 Zob. Z. Abramowiczówna, Wstęp w: Homer, Odyseja, przeł. L. Siemieński, oprac. J. Łanowski, Wrocław 1981, s. XVIII.

94 A. Fabianowski, dz. cyt., s. 52.

95 T. Konwicki, Mickiewiczowie młodsi, s. 466, 469. 
- protagonistów powieści, w które, jak się nam wydaje, już nie wierzymy. Poprzez Wyobraźnię i Strach możemy powrócić do naszego wspólnego źródła. [...]. Poprzez "maskę" swojej biografii i wielorakie maski swej twórczości udostępnia poeta całemu społeczeństwu obrzędowe znaczenie niewyrażalnych jaźni tego społeczeństwa, próbuje nie tylko „odtworzyć świadomość swej rasy”, co odzyskać jej nieświadomość. Nie możemy już wrócić do Raju nieskażonych Archetypów, ale możemy poddawać się marzeniom i wyobrażeniom, które oznaczają raj odzyskany. ${ }^{96}$

Oczywiście wskazane zależności w żaden sposób nie wyczerpują problematyki odwoływania się Konwickiego do dorobku Mickiewicza, która na wszystkich płaszczyznach jest na tyle bogata, że nie da się nawet wyliczyć tego typu praktyk artystycznych w tym miejscu. Proponowane ujęcie, jak wskazane to zostało na początku, nie obrało sobie za cel wyczerpania tematu, ale zasygnalizowanie problemu i zaproponowanie metodologii, wedle której można by podejść do sprawy. Najważniejsze było określenie sposobu obecności Mickiewicza i jego twórczości w dziełach Konwickiego, sposobu, który opiera się na uniwersalnych właściwościach ludzkiego umysłu, na myśleniu mitycznym, charakteryzującym się właśnie naddawaniem znaczeń i które wcale nie umarło, lecz - jak przekonuje Claude Lévi-Strauss - ciągle egzystuje, tyle że w zmienionej postaci, operując innym materiałem ${ }^{97}$. Zamiast więc czerpać ze starożytnych opowieści o bogach i herosach, współczesny pisarz, formułując mit, zwraca się ku literaturze. Jak przekonują przedstawiciele szkoły tartusko-moskiewskiej, „[...] w wielu dziełach sztuki neomitologicznej funkcję mitów spełniają teksty artystyczne (przeważnie typu narracyjnego), a rolę mitologemów - cytaty i parafrazy z tych tekstów. Bardzo często świat przedstawiony dekoduje się przy pomocy skomplikowanego systemu nawiązań i do MiTów, i do DZIEŁ ARTYSTYCZNYCH" ${ }^{98}$. Powyższe rozważania wskazały na pewną furtkę w badaniach nad twórczością autora Małej apokalipsy, na dotychczas w niewielkim stopniu wykorzystane tropy hermeneutyki mitów, naddawania znaczeń nad konkretnymi tekstami kultury, a także próbę scharakteryzowania schematu uniwersalnego scenariusza narracji Konwickiego, wszystkich jego zawiłości i izomorficzności, która nie jest niczym innym jak jedną z cech współczesnego języka neomitologicznie zorientowanej literatury XX wieku. Nie na darmo nazywa się Konwickiego wielkim „szamanem literatury” 99.

96 L.A. Fiedler, dz. cyt., s. 340-341.

97 Zob. C. Lévi-Strauss, Myśl nieoswojona. Tu zob. rozdz. Wiedza konkretu (s. 5-55), dotyczący m.in. pokrewności myślenia naukowego i mitycznego (zwł. s. 26, 36-37).

98 J. Łotman, Z. Minc, dz. cyt., s. 260, wyróżn. - M. K.

99 Określenie Stanisława Beresia i Pawła Huellego. Zob. S. Bereś, Konwicki: wielki szaman literatury, „Dziennik. Polska. Europa. Świat” 2006, nr 54, s. 32-33. 
Praktyka taka nie jest, wbrew temu, co głoszą niektórzy badacze, świadectwem braku indywidualności czy mówieniem językiem innego pisarza, ucieczką w tradycję czy epigonizmem. Wynika ona z konkretnego programu literackiego i określonego postrzegania funkcji literatury w planie aksjologicznym. Nie jest bezzasadne stwierdzenie, iż poznawanie twórczości Konwickiego, wgłębianie się w zawiłości narracji i potok wątków zmieszanych $z$ autobiografią, tradycją kultury czy literatury, wydaje się mieć w sobie coś $\mathrm{z}$ uczestnictwa $\mathrm{w}$ rycie inicjacyjnym, w swoistym misterium przezwyciężania obcości. Autor Sennika współczesnego bardzo ceni sobie rolę literatury w życiu ludzkim, o czym świadczą następujące sądy:

Sztuka jest to nasz jedyny bagaż i majątek. Padam plackiem wobec cywilizacji, biję czołem przed nauką i podziwiam wiele innych rzeczy, ale jedyne, czegośmy się tak naprawdę dorobili, to jest sztuka. Ona właśnie jest zapisem naszej obecności w galaktyce i wszechświecie. ${ }^{100}$

Ja usiłuję zracjonalizować, sprowadzić do intelektualnych form te wszystkie niepokoje i rozpacze, które ludzi męczą. I jeśli ktoś to czyta i widzi, że inny człowiek podobnie się szamocze, to dla niego znaczy, że nie jest najgorzej, bo nie jest sam. Że jesteśmy razem. Czy w tak zwanym świeckim życiu wiele więcej możemy zaproponować bliźniemu? ${ }^{\text {101 }}$

Przesłanie Konwickiego jest skoncentrowane na wartościach humanistycznych. Tylko sztuka, tylko literatura lub film mogą stanowić we współczesnym świecie, który wciąż nie może stanąć na nogi po katastrofie wartości, jedyną możliwość zbliżenia horyzontów, możliwość prawdziwego, głębokiego, bliskiego kontaktu z drugim człowiekiem. Żywym lub umarłym, tym, który tworzył wielkie dzieła narodowe o przeszło sto lat wcześniej i tym, który urodził się nawet długo po pisarzu, a wybiera się za każdym razem do kina na jego film lub z niecierpliwością wyczekuje kolejnego tomu dobrze znanej mu, ale jeszcze raz, inaczej opowiedzianej historii. Wiara Konwickiego w tak istotne, niemal sakralne przeznaczenie literatury jest $\mathrm{z}$ gruntu romantyczna. Sztuka staje się w ten sposób wielkim obrzędem, w którym „żywi i umarli wirują w szalonym tańcu” ${ }^{102}$ i w którym człowiek, „oszukany przez historię" ${ }^{103}$, ma szansę stać się guślarzem odbudowującym zniszczoną przez wiek XX świętą więź człowieka z drugim człowiekiem.

100 S. Bereś, Pół wieku czyśćca..., s. 147.

101 T. Konwicki, Jesteśmy wciąż tacy sami, z T. Konwickim rozmawia T. Sobolewski, „Litteraria Copernicana” 2008, nr 1, s. 205.

102 S. Bereś, dz. cyt., s. 85.

103 Zob. A. Nasalska, Oszukani przez historię. O prozie Tadeusza Konwickiego, w: Między literatura a historia, pod red. E. Łoch, Lublin 1986. 


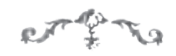

A B S T R A C T

\section{Mythical Presence of Adam Mickiewicz in Tadeusz Konwicki's Works}

The author tries to define the principle according to which tropes found in works and aspects of Adam Mickiewicz's biography exist in Tadeusz Konwicki's novels and films. The author of the paper claims that the figure of the great $19^{\text {th }}$ century poet, the various "legends" associated with him, and universally accepted interpretations of his works, have attained the status of a myth in the Polish culture, which exists in Polish common awareness as well as in artistic works of Konwicki. The author analyses the presence of Mickiewicz's motifs and characters in Konwicki's books and films, using the hermeneutical understanding of interpretation and the structural myth theory as the secondary semiological system, by employing the three narrative tiers: of Roland Barthes' functions, actions, and narration.

\section{KEYWORDS}

Adam Mickiewicz, biography, myth, Polish novel, Polish film, romanticism, Tadeusz Konwicki 